\title{
Training Program Using functional strength training to Develop Some Physical Abilities and Its Impact upon Defensive Follow-up of Basketball Players
} "Dr/ Heba Ahmed Ibrahim Ashour Research Summary:

The current research aims at identifying the effect of a proposed training program. The research sample consists of 18-year-old basketball players from Al-Mahalla Sports Club and registered in the Egyptian Basketball Federation (2018/2019) in Gharbia Governorate. The results showed that the proposed training program showed a positive effect on the physical abilities. The highest improvement in the tests was the test (weight gain from the front of the chest) The training program had a positive effect on the defensive follow-up, which was the result of defensive follow-up in pre measurement (20\%). (29\%) and improvement rate (45\%.)

Keywords: functional strength training - Defensive Follow-up

Introduction and problem of research- :

The process of training and learning in the group games is one of the basics of changing the level of performance of the players through the development of various physical components and technical skills and aspects of the line in a way that increases their ability to achieve better performance in the physical and technical changes and aspects of the hook and how to use them in matches
Mounir Girgis (2004) states that physical preparation is one of the most important elements of the training that depends on the development of the player, whether he is a beginner or advanced. It is an important basis that combines with the physical skills in the formation of the player physically. The player who is not physically prepared at the level of competition appears Fatigue and causing the result of the loss of the ball in addition to the weakness of the thinking of the planter or lack

\footnotetext{
"Instructor at the Department of Collective Games and Racquet Sports, Faculty of Physical Education, Tanta University
} 
thereof, on the contrary the player prepared physical end the game as it seemed to control the ball and thinking properly during the various stages of the game and the purpose of preparing the player physically to master the practice of the game, Flexibility Separating and strengthening muscle groups that are frequently used during play and increase their endurance (23:57)

Abdul Aziz Al-Nimr and Nariman Al-Khatib (2005) show that performance in all sports depends on how the body moves. The body moves by the muscles. It pulls and pulls the limbs from one location to another. The stronger the muscles, the more powerful the contractions are. The correction from a distance farther, and jump to the top, and the enemy faster and will enable him to perform better In addition to prevent the injury starts balanced development of force on the sides of different joints of the body between the muscle and the corresponding muscle, and perhaps highlight the factors leading to injuries due to the lack of development of force on The sides of these joints (9: 8)

Issam Abdel-Khaleq (2003) points out that the skillful performance is linked to the physical kinetic abilities of the intruders. The skillful performance depends on the development of the requirements of this performance of physical and motor abilities, especially the strength and muscular ability, flexibility, agility and balance. For these physical and kinetic qualities are special (11: 87)

Mohammed al-Shahat states that basketball is one of the most varied and dynamic sports activities that are used in these situations depending on the circumstances of the competition, the places of colleagues and competitors, and the lack of space of the stadium. This requires a basketball player to perform his skills with accuracy, speed and strength.

Issam Abdel-Khaleq (2003) points out that the compatibility between the muscles working in the movement depends on the mechanics of the muscular action, the compatibility works to be the contraction of the 
muscles in the joint in the direction required for the movement and regulates the nervous system internal compatibility in the same muscle and also between the working muscles, and work to reduce the degree The resistance caused by the muscles, which contributes significantly to the ability of the muscles working to produce more muscle strength. (11: 129)

According to the World Health Organization (WHO), health design group (2008) has shown that interest has recently become evident in the training of functional power. One of the methods of strength training, which stimulates the improvement of the functional capacity of bodies related to specific motor patterns in sports, is that it does not work in the same frame which works not in traditional body building exercises, but focuses on increasing the training strength of a single muscle group at the same time. The biggest focus is the increase in muscle strength, size and clarity. Such overload is required in job training, but the focus is on Movement focus on the strength of a particular muscle group. (33:3) Tiana Weiss (2010) points out that functional strength training can contribute as a way to improve the technical performance of young people compared to traditional methods, easily using their applications with different ages and physical abilities. All results confirm that strength training increases the efficiency of muscular strength, muscular endurance and balance. Variables are introduced into programs that use traditional methods and exercises. In addition, it is possible to develop flexibility through functional strength exercises that resemble the shape and nature of performance with a focus on the full motor range (39: 21)

Dean Olivar (2007) points out that there are four factors for success in basketball: $40 \%$ followed by attack, followed by $25 \%$, followed by $20 \%$ and finally 15\% free. (29: 85)

Jim Girland (2001) also stressed that follow-up requires good timing and control of the corrected youth to know the path of the ball and booking 
the striker and look at the ball and jump the highest possible possession of the ball The attacker performs a series of movements of focus and change the speed of the trend and if the defender tried a fastTo try to follow the ball (34:22)

The researcher sees through several games found that despite the speed of the technique of playing during the game, but follow-up to the ball, both follow-up and follow-up motivation, the success rate is negligible where the follow-up of the fundamentals of mobility in basketball and became the struggle under the basket to get to the ball for Winning the games is also considered to be the most important and competitive part of the matches at all levels of competition, but it may have a great impact in the games more because of the high proportion of missed correction of the players and the reason that the follow-up at the beginning depends on the play takes a step in front of The attacker depends on the maximum strength constant and depends on the maximum strength of moving in the case of the player to distinguish the striker and at the same time playing the attacker resisting the game depends on the strength of the fixed and then player defender to take the ball and depends on the dynamic strength of that follow-up. Basketball is dependent on the practice of the upper limb muscles beside the muscles of the lower limb. The muscles in the lower end of the basketball players are known to produce a large amount of strength and ability but do not connect fully to the upper limb due to the weakness of the muscles of the center area and responsible for the strength of the party The researcher also finds that as a result of the absence of force training, the period of preparation that results from the lack of muscle strength that depends on the performance of offensive and defensive skills and defensive follow-up depends on the high efficiency of muscle strength and muscular strength and balance, which clearly shows the performance The player in the games, which prompted the researcher to try to find a way to remedy this problem is the use of job training works to strengthen the center, which 
helps to transfer the force produced from one party to another and be in full flow with the province boil the lack of power from the center, In addition to generating power in the center area, which increases the amount and amount of power transferred from the bottom of the body to the top, as the researcher believes that the factors that help overcome the weak level of skill performance is the development of functional force, which affects the balance between strength and muscle strength and flexibility, and this Make the researcher develop a program using job training.

This is in line with Essam Abdel-Hamid Marawan Ali (2014) 30, Nasr Hilmi (2009) 3, Tarek Salah (2008), 7 Nada Ramah and Anrieman Husseini (2005) (2010) (26) that the training of functional strength has led to the improvement of the balance of fixed and moving levels of strength and speed and strength of muscles of the two men and back and muscle capacity in varying degrees to improve the level of skill performance.

Research goals-:
-The objective of the research is to design a training program using job training and to identify:

-The effect of the use of training on (some physical variables) in the research.

-The impact of the use of job training on defense follow-up.

Research hypotheses-:

1-There are statistically significant differences between the mean and postexperimental measurements of the experimental group in the physical variables in favor of the post-measurement

2-There are statistically significant differences between the mean of the pre and the post measurements of the experimental group in the defensive follow-up for the benefit of the post

\section{Search procedures-:}

\section{Research Methodology-:}

The researcher used the experimental method in order to adapt it to the nature of the research and its procedures using experimental design with a pre and post measurement experimental group.

The research sample-:

The research sample was chosen in a deliberate manner by the 19-year-old basketball 
players from the Mahalla Sports Municipality and registered in the Egyptian

Basketball

Federation

$(1018 / 2019)$ in Gharbia

Governorate.

\section{Table (1)}

Characterization of the sample in the variables of the growth parameters in question to show the moderation of the data

\begin{tabular}{|c|c|c|c|c|c|c|}
\hline Series & Variable & $\begin{array}{l}\text { Measure } \\
\text { unit }\end{array}$ & SMA & $\begin{array}{l}\text { standard } \\
\text { deviation }\end{array}$ & Flattening & Sprain \\
\hline 1 & Height & $\overline{\mathrm{Cm}}$ & 187.75 & 4.26 & 0.73 & -0.58 \\
\hline 2 & Age & Year & 18.46 & 0.72 & & $\overline{0.086}$ \\
\hline 3 & Weight & $\mathrm{Kg}$ & 72.75 & 2.31 & & -0.42 \\
\hline 4 & $\begin{array}{l}\text { Training } \\
\text { age }\end{array}$ & Year & 2.50 & 0.37 & -0.70 & 0.3 \\
\hline \multicolumn{4}{|c|}{$\begin{array}{l}\text { Table (1) shows the } \\
\text { arithmetic mean, standard } \\
\text { deviation, } \\
\text { coefficient, and toning } \\
\text { coefficient of the variables in } \\
\text { question. The meanness of the } \\
\text { data is shown as the values of } \\
\text { the torsion coefficient ranged } \\
\text { between } \pm 3 \text {, which gives a } \\
\text { direct indication of the absence } \\
\text { of data from irregular } \\
\text { distribution defects. }\end{array}$} & \multicolumn{3}{|c|}{$\begin{array}{l}\text { conducted on } 1 / 1 / 2018 \text {. The } \\
\text { survey studies were conducted } \\
\text { to train the assistants on the } \\
\text { different measurement methods } \\
\text { as well as to ensure the safety } \\
\text { of the equipment and the } \\
\text { physical tests in the research } \\
\text { and the end of the research } \\
\text { (30/3/2018) } \\
\text { measurements of the physical } \\
\text { tests were carried out. } \\
\text { (C) Human domain: } \\
\text { (16) players were chosen } \\
\text { as the basic research sample of }\end{array}$} \\
\hline \multicolumn{4}{|c|}{$\begin{array}{l}\text { A. Spatial domain: } \\
\text { The research was carried }\end{array}$} & \multicolumn{3}{|c|}{$\begin{array}{l}\text { as the basic research sample of } \\
\text { the } 18 \text {-year-old Mahalla }\end{array}$} \\
\hline \multicolumn{4}{|c|}{$\begin{array}{l}\text { out in Al-Mahalla Municipal } \\
\text { Club in Gharbia Governorate } \\
\text { in the } 2018 / 2019 \text { season } \\
\text { B. Time domain: }\end{array}$} & $\begin{array}{l}\text { Municipal } \\
\text { registered } \\
\text { Basketball } \\
2018 / 2019\end{array}$ & \multicolumn{2}{|c|}{$\begin{array}{l}\text { Footballers and } \\
\text { in the Egyptian } \\
\text { Federation }\end{array}$} \\
\hline
\end{tabular}

The study took a period of time

(3 months). The research was

Table (2) 
Characterization of the sample in the physical and skill measurements to demonstrate the moderation of the data

\begin{tabular}{|c|c|c|c|c|c|}
\hline Variable & $\begin{array}{l}\text { Measur } \\
\text { e unit }\end{array}$ & SMA & $\begin{array}{l}\text { standard } \\
\text { deviation }\end{array}$ & Flattening & Sprains \\
\hline Push the foot & $\mathrm{Kg}$ & 110.2 & 0.83 & -0.93 & 0.01 \\
\hline $\begin{array}{l}\text { Push the weight of the } \\
\text { front of the chest }\end{array}$ & $\mathrm{Kg}$ & 32.75 & 0.63 & -0.43 & 0.08 \\
\hline $\begin{array}{l}\text { The attraction from the } \\
\text { ground to the chest }\end{array}$ & $\mathrm{Kg}$ & 27.65 & 2.49 & -1.57 & 0.31 \\
\hline Vertical jump of stability & $\mathrm{Cm}$ & 45.20 & 2.64 & -0.49 & 0.36 \\
\hline Immobility of sitting 30 seconds & Repletion & 22.65 & 3.31 & -0.48 & 0.74 \\
\hline $\begin{array}{l}\text { Push the trunk of the } \\
\text { oblique slant } 30 \text { seconds }\end{array}$ & Repletion & 20.25 & 2.67 & -0.52 & 0.21 \\
\hline $\begin{array}{l}\text { Throw a medical ball from } \\
\text { sitting } 3 \mathrm{~kg}\end{array}$ & $\mathrm{Cm}$ & 4.95 & 2.11 & 0.27 & 1.00 \\
\hline $\begin{array}{l}\text { Stand on one foot (static } \\
\text { balance) }\end{array}$ & $S$ & 2.01 & 1.53 & 1.38 & 0.96 \\
\hline $\begin{array}{l}\text { Dynamic Balance (Figure } \\
\text { Eight) }\end{array}$ & No & 5.47 & 0.55 & 1.55 & 0.08 \\
\hline $\begin{array}{l}\text { Defensive follow-up (30 } \\
\text { seconds) }\end{array}$ & Repletion & 20 & 1.24 & 1.47 & 1.23 \\
\hline \multicolumn{2}{|c|}{$\begin{array}{l}\text { Table (2) shows that the } \\
\text { values of the torsion coefficient } \\
\text { in the physical measurements } \\
\text { and measurements of the } \\
\text { defensive follow-up level were } \\
\text { limited to }( \pm 3) \text {, indicating that } \\
\text { the research community is free } \\
\text { of defects of non-uniform } \\
\text { distributions, indicating }\end{array}$} & \multicolumn{4}{|c|}{$\begin{array}{l}\text { homogeneity of the sample } \\
\text { members in these variables. } \\
\text { Data collection tools- : } \\
\text { The researcher used the } \\
\text { following tools to collect data: } \\
\text {-Analysis of references and } \\
\text { previous studies. } \\
\text {-Physical tests in question. }\end{array}$} \\
\hline
\end{tabular}




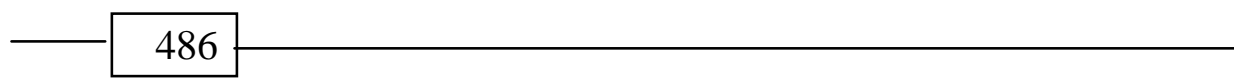

Table (3)

Tests used in research

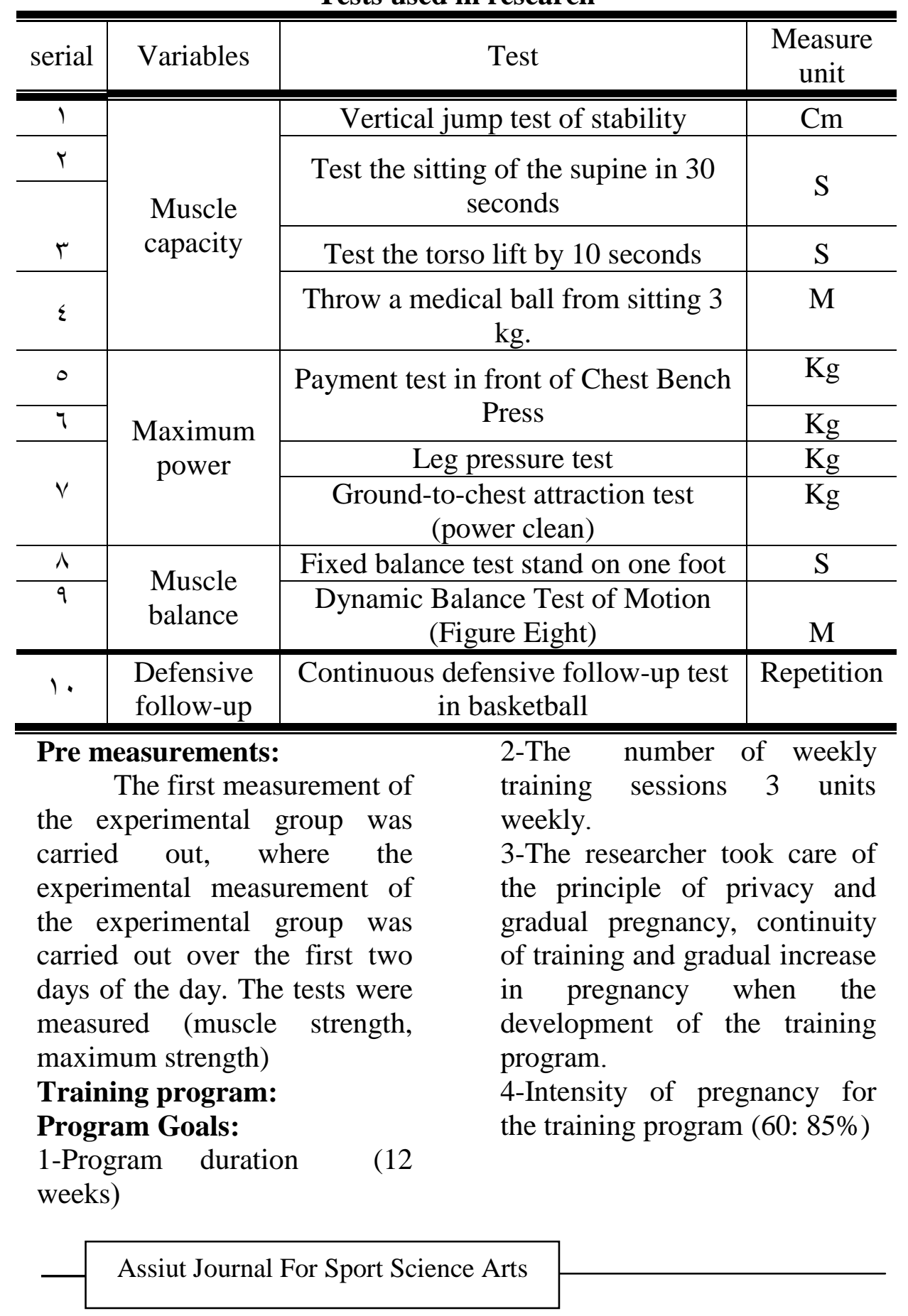


Table (4)

Indication of the differences between the median of the pre and the post measurements of the experimental group in the physical variables under study $n=18$

\begin{tabular}{|c|c|c|c|c|c|c|c|}
\hline Variables & $\begin{array}{l}\text { Measure } \\
\text { unit }\end{array}$ & $\begin{array}{l}\text { Average pre } \\
\text { measurement }\end{array}$ & $\begin{array}{c}\text { Average } \\
\text { post } \\
\text { measurement }\end{array}$ & $\begin{array}{c}\text { Average } \\
\text { differences }\end{array}$ & $\begin{array}{c}\begin{array}{c}\text { Standard } \\
\text { deviation } \\
\text { of } \\
\text { differences }\end{array} \\
\end{array}$ & $\begin{array}{c}\mathbf{T} \\
\text { value }\end{array}$ & $\begin{array}{l}\text { Eta } 2 \\
\text { value }\end{array}$ \\
\hline $\begin{array}{l}\text { Push the } \\
\text { foot }\end{array}$ & $\mathrm{Kg}$ & 110.2 & 125.8 & 15.6 & 0.78 & 2.33 & 0.87 \\
\hline $\begin{array}{l}\text { Push the } \\
\text { weight of } \\
\text { the front of } \\
\text { the chest }\end{array}$ & $\mathrm{Kg}$ & 32.75 & 55.7 & 22.95 & 1.24 & 5.25 & 0.93 \\
\hline $\begin{array}{l}\text { The } \\
\text { attraction } \\
\text { from the } \\
\text { ground to } \\
\text { the chest }\end{array}$ & $\mathrm{Kg}$ & 27.65 & 35 & 7.35 & 2.01 & 7.15 & 0.79 \\
\hline $\begin{array}{l}\text { Vertical } \\
\text { jump of } \\
\text { stability }\end{array}$ & $\mathrm{Cm}$ & 45.20 & 66.7 & 21.5 & 1.54 & 4.23 & 0.81 \\
\hline $\begin{array}{l}\text { Immobility } \\
\text { of sitting } \\
30 \text { seconds }\end{array}$ & Repletion & 22.65 & 35.9 & 13.25 & 2.1 & 2.97 & 0.89 \\
\hline $\begin{array}{l}\text { Push the } \\
\text { trunk of } \\
\text { the oblique } \\
\text { slant } 30 \\
\text { seconds }\end{array}$ & Repletion & 20.25 & 33.8 & 13.55 & 2.24 & 3.12 & 0.96 \\
\hline $\begin{array}{l}\text { Throw a } \\
\text { medical } \\
\text { ball from } \\
\text { sitting } 3 \mathrm{~kg}\end{array}$ & $\mathrm{Cm}$ & 4.95 & 5.7 & 0.75 & 2.57 & 4.01 & 0.84 \\
\hline $\begin{array}{l}\text { Stand on } \\
\text { one foot } \\
\text { (static } \\
\text { balance) }\end{array}$ & S & 2.01 & 3.16 & 1.15 & 0.33 & 19.16 & 0.93 \\
\hline $\begin{array}{l}\text { Dynamic } \\
\text { Balance } \\
\text { (Figure } \\
\text { Eight) }\end{array}$ & No & 5.47 & 2.67 & 2.80 & 1.10 & 14.00 & 0.87 \\
\hline
\end{tabular}

Table $(\mathrm{T})$ value at a significant level $(0.05)=2.11$

Table (4) shows the direction of post, and the statistically significant differences between the mean and post measures of the research group in the physical variables in the research and in ETA parameters showed a significant effect of the proposed program on improving the physical aspects of the sample in question. 
Table (5)

Indication of the differences between the median of the pre and the post measurements of the experimental group In the defense follow-up under study $n=18$

\begin{tabular}{c|c|c|c|c|c|c|c}
\hline \hline Variables & $\begin{array}{r}\text { Measure } \\
\text { unit }\end{array}$ & $\begin{array}{r}\text { Average pre } \\
\text { measurement }\end{array}$ & $\begin{array}{r}\text { Average } \\
\text { post } \\
\text { measurement }\end{array}$ & $\begin{array}{r}\text { Average } \\
\text { differences }\end{array}$ & $\begin{array}{r}\text { Standard } \\
\text { deviation } \\
\text { of } \\
\text { differences }\end{array}$ & $\begin{array}{r}\text { T } \\
\text { value }\end{array}$ & $\begin{array}{r}\text { Eta 2 } \\
\text { value }\end{array}$ \\
\hline $\begin{array}{c}\text { Defensive } \\
\text { follow-up } \\
(30) \\
\text { seconds }\end{array}$ & Repetition & 20 & 29 & 9 & 1.2 & 3.19 & 0.97 \\
\hline \hline
\end{tabular}

Table $(\mathrm{T})$ value at a significant level $(0.05)=2.11$

Table

(5) shows statistically significant differences between the mean and post measurements of the research group in the follow-up test in the research and in the

Table (6)

direction of post, and the ETA parameters showed a significant effect of the proposed program on improving the physical aspects of the sample in question.

Percentage improvement between pre-measurement of physical variables and defensive follow-up And post-physical tests and defensive level of follow-up

\begin{tabular}{|c|c|c|c|c|c|c|}
\hline \multirow[b]{2}{*}{$\begin{array}{l}\text { Ser } \\
\text { ial }\end{array}$} & \multirow[b]{2}{*}{ Variables } & \multirow{2}{*}{$\begin{array}{l}\text { Mea } \\
\text { sure } \\
\text { unit }\end{array}$} & \multicolumn{4}{|r|}{ Data } \\
\hline & & & $\begin{array}{r}\text { Pre } \\
\text { average }\end{array}$ & $\begin{array}{l}\text { Post- } \\
\text { average }\end{array}$ & $\begin{array}{l}\text { Differenc } \\
\text { e between } \\
\text { averages }\end{array}$ & $\begin{array}{l}\text { Improveme } \\
\text { nt ratio \% }\end{array}$ \\
\hline 1 & Push the foot & $\mathrm{Kg}$ & 110.2 & 125.8 & 15.6 & $14.15 \%$ \\
\hline 2 & $\begin{array}{l}\text { Push the weight of the } \\
\text { front of the chest }\end{array}$ & $\mathrm{Kg}$ & 32.75 & 55.7 & 22.95 & $70.07 \%$ \\
\hline 3 & $\begin{array}{l}\text { The attraction from the } \\
\text { ground to the chest }\end{array}$ & $\mathrm{Kg}$ & 27.65 & 35 & 7.35 & $26.58 \%$ \\
\hline 4 & $\begin{array}{lll}\text { Vertical jump of } \\
\text { stability }\end{array}$ & $\mathrm{Cm}$ & 45.20 & 66.7 & 21.5 & $47.56 \%$ \\
\hline 5 & $\begin{array}{l}\text { Immobility of sitting } \\
30 \text { seconds }\end{array}$ & $\begin{array}{l}\text { Repl } \\
\text { etion }\end{array}$ & 22.65 & 35.9 & 13.25 & $58.49 \%$ \\
\hline 6 & $\begin{array}{l}\text { Push the trunk of the } \\
\text { oblique slant } 30 \text { seconds }\end{array}$ & $\begin{array}{l}\text { Repl } \\
\text { etion }\end{array}$ & 20.25 & 33.8 & 13.55 & $66.91 \%$ \\
\hline
\end{tabular}


Follow Table (6)

Percentage improvement between pre-measurement of physical variables and defensive follow-up And post-physical tests and defensive level of follow-up

\begin{tabular}{|c|c|c|c|c|c|c|}
\hline \multirow[b]{2}{*}{$\begin{array}{l}\text { Ser } \\
\text { ial }\end{array}$} & \multirow[b]{2}{*}{ Variables } & \multirow{2}{*}{$\begin{array}{l}\text { Mea } \\
\text { sure } \\
\text { unit }\end{array}$} & \multicolumn{4}{|r|}{ Data } \\
\hline & & & $\begin{array}{r}\text { Pre } \\
\text { average }\end{array}$ & $\begin{array}{l}\text { Post- } \\
\text { average }\end{array}$ & $\begin{array}{l}\text { Differenc } \\
\text { e between } \\
\text { averages }\end{array}$ & $\begin{array}{l}\text { Improveme } \\
\text { nt ratio \% }\end{array}$ \\
\hline 7 & $\begin{array}{l}\text { Throw a medical ball } \\
\text { from sitting } 3 \mathrm{~kg}\end{array}$ & $\mathrm{Cm}$ & 4.95 & 5.7 & 0.75 & $13.15 \%$ \\
\hline 8 & $\begin{array}{l}\text { Stand on one foot } \\
\text { (static balance) }\end{array}$ & $\mathrm{S}$ & 2.01 & 3.16 & 1.15 & $57.21 \%$ \\
\hline 9 & $\begin{array}{l}\text { Dynamic Balance } \\
\text { (Figure Eight) }\end{array}$ & No & 5.47 & 2.67 & 2.80 & $51.18 \%$ \\
\hline 10 & $\begin{array}{l}\text { Defensive follow-up } \\
\text { (30 seconds) }\end{array}$ & $\begin{array}{l}\text { Repl } \\
\text { etion }\end{array}$ & 20 & 29 & 9 & $45 \%$ \\
\hline
\end{tabular}

\section{Research Discussion :}

In light of the results of the statistical analysis, the limits of the measurements used, and through the research objectives, the researcher was able to discuss the results as follows:

Discussion of the first hypothesis, which states that "There are statistically significant differences between the average of the pre and post measurements of the experimental group in the physical variables in favor of post"

Table (2) shows that statistically significant differences between the mean and the post-test parameters of the experimental group were found in physical variables in favor of post at a significant level of 0.05 where $\mathrm{T}$ was calculated higher than the tabular value $(\mathrm{T}) \quad(2,33)$ was higher than (T) and $(2.15 \%)$ was in the test of weight gain in front of chest $(\mathrm{T})$ calculated $(5,25)$ higher than (t) The improvement rate $(70.07 \%)$ was in the ground-to-chest traction test calculated $(7,15)$ higher than the $(\mathrm{T})$ table $(2,11)$ and the improvement rate $(26.58 \%)$. In the vertical jump test of calculated stability (4.33) (2.11). The improvement rate $(47.56 \%)$ was in the measured sitting (T) 
regression test (2.97) higher than the (T) (3.32) was higher than the (T) score (2.11). The improvement rate $(66.91 \%)$ was in the test of throwing a medical ball from the sitting $\mathrm{C}$ ) calculated $(4,00)$ higher than $(t)$ the table (2.11) and the improvement rate $(63.15 \%)$

The researcher pointed out that this improvement was achieved by the use of job training in the search, which contains training directed directly to the development of muscle strength and maximum strength to improve the level of physical performance of players and agrees with each of the study, "Ashraf Yahya Awad," (2013) "Mohamed Othman Mohamed Ahmed" (2012), 20 "Mahmoud Abdel Mohsen" (2013) (22), "Marwan Ali (2013)" (37), the study of Udine and Samarain, Alauddin Samirance (2012) The program, using functional training, improved muscle capacity and increased the maximum muscle strength which led to the development of muscular capacity, motor speed and muscular endurance. In the valley to improve the physical level of the players.
Scott Schenes (2003) (38) agrees that the importance of job training leads to indirect effects on the muscles, by increasing the productive force of a movement that can be used to improve physical and nervous performance. Functional strength training.

There was a marked improvement in the level of equilibrium in the fixed equilibrium test (standing on one foot), where the average of the pre measurement (2.01) was swallowed while the mean distance measurement (19.16) and the improvement rate (57.21) ). The average of the pre measurement was (5.47), while the mean distance measurement (14.00) and improvement rate (51.18)

The researcher pointed out that these differences between the measurements to the quality of the exercises used in the training program using free exercises, and using elastic resistors such as the ropes, Swiss balls, which are based on the work center area (mid body), which had a positive impact on the improvement of balance, It helps to improve the physical and motor performance of the 
different basic skills in question, which requires a balance of quality to show performance in a good image and increasingly.

The results of this study are consistent with the results of the study of Rami Salama (2011). 5. Jehan Al-Sawy (2011) (4), Rida Ibrahim (2009), 6 (Osama) The strengthening of the muscles of the abdomen and the back of the corresponding (balance muscle), ie, balance Bettn strengthen the front muscles and back muscles in an effective manner depends largely on the test of a set of exercises appropriate to each sport, and the included in this sport of different skills and movements and also the stage of the age that will be performed This group of exercises.

This is also confirmed by Mohammed Allawi and Mohamed Nasr El Din (2001). Many sports activities depend on maintaining the center of the body moving over the base of the base during the performance, until the body becomes more stable and balanced, especially when performing different motor skills (15:42)

In this regard, Fabio Comana (2004) emphasizes that balance is an essential element in functional training, not only the balance between strength and flexibility or working muscles and nonfunctioning muscles, but also what we may think are means used. For example, stand on one foot and be capable of moving other discount members without dropping, this feature is an important interactive training job. (31: 75)

In the discussion of the results, the first hypothesis that "there are statistically significant differences between the mean and postexperimental measurements of the experimental group in physical variables for the benefit of post "

Discussion of the second hypothesis, which states that "There are statistically significant differences between the average of the pre and postexperimental measurements of the experimental group in defensive follow-up for the benefit of post " 
Table (3) shows that there are statistically significant differences between the averages of the pre and post measures of the experimental group in the technical variables for the benefit of the post, where (t) calculated for defensive follow-up (3.19) was higher than the tabular value (2.11) Improvement (45\%) The researcher points out that this improvement in defensive follow-up is due to the use of job training. It has a positive effect on defense follow-up and skill areas. This is due to the physical aspect. Basketball is also an interesting $\mathrm{A}$ researcher in the functional approach, which allows the possibility of correct time division of the path of muscle strength during the performance, which led to improved defensive follow-up in the search.

This is consistent with Hamid, Marawan Ali (2014) Abdel Essam (30), (36) (2013) Marwan Ali Ashraf Yahya (2013) (2), Tariq Salah (2008) Which resulted from job training has grown through handball exercises that use jump training and muscle strength plays a crucial role in the transmission of play from attack to defense and vice versa.

This is confirmed by Kamal Abdel-Hamid and Subhi Hassanein (2002) that success in any basic defensive or offensive skill requires physical abilities such as muscular strength, strength and balance and also needs to perform more than a physical component (13: 54)

In this regard, Mohamed Hassan Allawi and Mohamed Nasr El Din (2001) indicate that muscle strength is positively correlated with athletic performance in some motor activities and that motor performance in the field of athletic activity depends to varying degrees on muscle strength (15:84)

As well as the study of Ahmed Salama Saber (2010), 27 (Amr Saber, 2012). 12 The study of Kelly and others (2012) (35) indicates that the improvement of physical abilities leads to an increase in the improvement of skill capacity such as offensive and defensive follow-up.

The second hypothesis, which states that "there are statistically significant 
differences between the average of the pre and post measures of the experimental group in defensive follow-up for the benefit of post"

Conclusions:

-The training program has a positive impact on the variables regardless of (muscle capacity - maximum strength balance)

-The program showed an improvement in physical abilities in post-measurement. The highest improvement was in the test (chest weight gain), $70.07 \%$, and the lowest improvement in the test (throwing a medical ball from sitting $3 \mathrm{~kg}$ ) and $13.15(\%)$

-The program has a positive effect on defensive follow-up, where pre measurement (20), post (29) and improvement rate (45\%)

\section{Recommendations:}

-The application of the proposed program using the same job training and the intensity of inter-comfort on the basketball players to improve the muscular capacity of the passengers and arms and the maximum forces and the balance of fixed and moving in addition to defensive followup. -the need to put basketball coaches in their training some of the strength training career. -Re-conduct such research on other samples differ in sex, age and exercise activity.

\section{References}

1-Abdul Aziz Al-Nimr, Nariman Al-Khatib (2000): Physical preparation and weight training for pre-puberty youth, first edition, teachers of sports book, Cairo.

\section{2-Abdul Aziz Al-Nimr and} Nariman Al-Khatib (2005), muscular strength (design of force programs and planning of the training season), the book center for publishing.

3-Abdul-Aziz Al-Nimr and Nariman Al-Khatib (2007): Muscle strength (design of force programs and planning of the training season), the book center for publishing.

\section{4- Ahmed salaam saber} (2010): effects of are commended training device on developing rebound skill(attack -defense)of basketball player, world journal of sports sciences 3(s);144-148.

\section{5- Aladdin sheikh,samiran} modal (2012): effect functional training physical fitness component son college male students- a pilot stud, 
journal of humanities and social seience, volume, issue2, pp 01.05

6-Amr Saber Hamza (2012) Effect of the training of the functional elements of the major blood and agility reaction and the level of performance of motor skills for the young match, Journal of Science and Arts, Faculty of Sports, Assiut University.

\section{7-Ashraf Yahya Shehata} (2013): Designing a training program for handball players, unpublished $\mathrm{PhD}$ thesis, Faculty of Mathematical Sciences, Helwan University.

8- Dean liver/Kevin peloton :(2007): a starting point for analyzing basketball statistics journal of quantitative analysis in sports.

9- Essam Abdel- hammed mar wan ail (2014): effect of function al strength exercise on testosterone hormone and shooting with the top jumping for handball player, sports science and physical education in the Arab nation "future vision" el mania university,14-16 April.

10- Essam Abdel- Khaliq (2003): Mathematical Training (Theories and Applications),
Edition for Publishing and Distribution, I 11

11- Fabio command; (2004): function training for sports humankineties;) (champing12, englad

12- Gray cook (2003): core athletic body in balance; performance

13-Health design group (2008): train to win ,fun cationic trani ing \&core stabilization, fun cationic exercise training program that train movements ,not just muscles

14- Intsar Abdel - Ghazi Helmy: The effectiveness of jazz program) and the training of functional integration on some special physical variables and the level of performance of some movements in modern dance published. Third International Scientific Conference, Volume IV, Faculty of Mathematical Sciences Zagazig University 15- Jehan Yousef Al-Sawy (2011): Effectiveness of Functional Strength Exercises on Some Physical Variables and Performance Level in Taekwondo Women, Scientific Journal of Physical Education Sciences, May 20-21, Consta, Romania. 
16- Jim garland (2001) the baffled parents guide to great basketball drills.

17-Kamal Abdul Hamid Ismail and Mohammed Subhi Hassanein (2002): Quartet handball modern (Part III), the Center for the book for publication.

\section{8-Kamal}

Abdel-Hamid

Ismail (2016): Performance measurement and evaluation tests associated with human movement science, Faculty of Physical Education Boys, Zagazig University, book center for publishing, Cairo.

19- Kelly. Et al (2012): effects of a lower limb functional exercise program me aimed at maiming knee valage on running kinematic in youth athletes ,physical the repay in sprot,pp.1-5

20- Mar wan ail abdall, mohmoud abdelmohsen (2014): core stability relation to physical performance in some collectivity games theories \&application, the internation edition faculity of phycail education Abu qir ,Alexandria university ,volume no11july

21-Mahmoud Abdel Mohsen Abdel-Rahman (2013): Effect of multi-level training program on trunk muscles on the physical variables and the performance of the skills of the wall of resistance and the overwhelming beating in volleyball, published research, the 11th International Conference of Sport and Movement Science between theory and practice, Alexandria University.

\section{2-Mohamed Hassan Allawi} and Mohamed Nasreddin Radwan (2001): Performance tests of motor, I 3, Dar Al-Fikr Al-Arabi, Cairo.

23- Mohammed Mohammed Al- Shahat: Basketball ball, his office of faith, Mansoura, 2004

\section{4- Mohammad Ramadan} Al-Alfi (2017): Training program to improve the movements of the feet and its impact on the level of performance of some offensive skills for basketball players, Master thesis published, Tanta University.

\section{5- Mohamed}

Osman

Mohamed (2012): Effect of a training program for the highest muscular ability of basketball players, Master Thesis, Faculty of Physical Education, Helwan University. 
26- Mohamed Sobhi Hassanein

(1999):

Measurement and Evaluation in Physical Education and Sports, Part I. The fourth edition. Arab Thought, Cairo

27-Mohamed

Sobhi

Hassanein,

Mohamed

Mahmoud Abdel- Dayem (1999): Modern in Basketball: The Scientific and Applied Foundations EducationTraining- MeasurementSelection of the Law of Arab Thought Management Cairo

28- Mohamed Sobhi Hassanein (2004):

Measurement and Evaluation in Physical Education and Sports, Part I, I 6, Dar Al Fikr Al Arabi, Cairo.

29- Morgan wooten (2013): education coaching basketball physical successfully, human kinetics, champaign

30- Munir Girgis Ibrahim: Comprehensive Training and Skill Discrimination, Dar AlFikr Al-Arabi, Cairo, 2004.

\section{1-Mustafa Mustafa Al-}

Fateh: Scientific Encyclopedia for the training of youth in the field of sports, Minia University, 2014

32- Nada Hamed Ramah and Nariman Mahmoud AlHusseini: The Effectiveness of
Integrative Functional Exercises on Some Physical Variables and Performance Levels on Ground Movements, Journal of Comprehensive Education Research, Volume II 33-Wajdi Mustafa Al-Fateh: Theories and applications of physical preparation of young people in the field of sports, Minia University 2016.

\section{4-Osama Abdel Rahman Ali} (2008): Effectiveness of strength training on bone mineral density and the strength of speed and balance and the level of performance of the skills of challenge and jump to the original fencing. Research publication, the conference before the International Olympiad of Mathematical Engineering Sciences, University of Natig, China

35-Rami Salama AbdelHafeez (2011): A proposed training program for the functional force to improve some physical and skill changes for the originator of football, Master thesis published, Helwan University.

36-Riza Mohammed Ibrahim (2009): Effectiveness of the strength training on the strength of the muscles of the 
center and the driving forces and its relation to the level of skill performance in the swimming crawling on the back, Master Thesis, Faculty of Physical Education for Girls, Zagazig University.

37- Scott gains (2003): benefits and limitation of functional exercise vertex fitness,nesta,u.s.a

38- Tariq Salaheddin Syed (2008): The effectiveness of the training of the functional force on some of the physical, psychological and dynamic variables and their relationship to the level of performance of handball players, International Journal of Science and Sports Movement, University of Sofia،

39- Tiana weiss, jerica kreitinger, hilarywilde, chris wiora,michellesteegelance dalleck, Jeffrey janot., (2010): effect of functional resistance training on muscular fitness outcomes in young adults,jexers sci fit. Vol8.no2.pp113-122. 